\title{
Regional Symposium of World Psychiatric Association in Jaipur, India
}

\author{
Geoffrey Wallis, Consultant Psychiatrist, Fulford Grange Hospital, Rawdon, Leeds
}

Much of the initiative for this symposium, held between 6 and 8 January 1985, came from Professor Shridhar Sharma, President of the Indian Psychiatric Society, and the 38th Annual Conference of the Indian Psychiatric Society, at which there was a record number of participants, was held immediately before and in the same place as the Symposium. Many of the psychiatrists who attended the IPS Conference stayed on for the Symposium, where they somewhat outnumbered their foreign colleagues. The premises were the Medical College and Hospital named after Sawai Man Singhji, a Maharaja of Jaipur. The complex is a little way outside a crenellated pink wall surrounding the equally pink and fascinating Jaipur in Rajasthan, North India. The site, enhanced by a large marquee for refreshments, was very pleasant.

The Symposium theme was 'Psychosocial Stress and Mental Health'. My selecting papers from an enterprising programme is unfair because I could not hear them all but a few seemed to stand out. Dr N. N. Wig spoke on the current revision, in which he was playing a major part, of the psychiatric section of ICD9, defending the need for it against DSMIII. Dr Hanne Schulsinger of Copenhagen, wife of the Secretary General of the WPA, who with the WPA President, Dr Costas Stefanis from Athens, was at the meeting, described the longitudinal prospective study which started in 1962 and has demonstrated resilience and 'invulnerability factors' in children at high risk for schizophrenia, such as those with a schizophrenic parent. Also from Copenhagen, Dr Marianne Kastrup reported a decade's study revealing anxiety and allied symptoms among several hundred victims of torture while they had been political prisoners. Dr Desmond Kelly enthralled his audience with an account of professional 'burn out'. Dr Ivor Jones related how in Australian aborigines social control by magic, organised spearing between males and clubbing between females were being replaced by more orthodox methods, a consequence being great increases in violence and alcohol consumption. Another Australian, Dr John Grigor, told of social stresses resulting from his government's promotions of immigration as a means of increasing the population and of closer links with nearby countries. He startled us with the suggestion that the Nazis had in some communities wiped out the schizophrenic gene. Professor Antonio Balestrieri of Verona gave a reasonable vindication of the sudden discharge of Italian inpatients into the community. Dr Tejpal Jindal from New Delhi, with a fine disregard for 'Psychiatry Limited' and Freud's pessimism, urged that psychiatrists should lead everybody to break national boundaries and become 'citizens of earth', so that all nations would regard arms of war as 'useless garbage'.
Some papers were spoiled by the elementary defects of an enormous amount of information in tiny print on slides and poor microphone technique. While I was sitting by the speakers in the chair I could hear them clearly but in the auditorium their voices came as continuous echoing booms or tiny rapid whispers. Could the WPA emulate our College in determined efforts to remedy these barriers to communication?

They did not, however, mar the social and cultural functions and the hospitality of the organisers. Again I am reluctant to pick some from the many but Professor J. N. Vyas, Head of the Department of Psychiatry and Superintendent of the Psychiatry Centre in the SMS complex and chairman of this symposium's Organising Committee, and his staff, including registrars, were attentive, kind and generous hosts.

Indian psychiatry has always been community orientated. At the behest of the British Raj some asylums were built to protect the community but they are being replaced by psychiatric units such as the one in Jaipur, which has 280 beds as well as a 22 bedded 'emergency' ward which, unlike the other wards, can admit patients informally. For every million Indians there are 36 psychiatric beds, .8 psychiatrists, .4 psychiatric nurses, .6 clinical psychologists and .6 psychiatric social workers but for a population of over 34 million the psychiatric centre at Jaipur has an annual outpatient attendance of 70,000 . A survey indicates that $6.5 \%$ of the population suffers from mental disease and after prolonged pressure from the IPS a National Mental Health Programme started in 1982. Psychiatrists have since 1981 resisted modification of a Lunacy Act of 1912 by a Mental Health Act because they believe it would isolate mental from other illnesses. Teaching and research are increasing.

The population of India being about 712 million and still growing, the demographic unit tends to be a 'lac' of 100,000 . Some $45 \%$ is aged under 15 . There is apparently not much unemployment but the annual per capita income is less than US\$100 and, particularly in Bombay, I saw and smelled gross crowding, poverty and people living on the pavements. Perhaps one reason why every day a generation of the same magnitude of the population of Australia is said to be reproduced is that the Hindus, who constitute more than $80 \%$ of the population, stimulate marital sex. Among doctors' advertisements of their services was one outside a sordid house in Bombay for state financed 'Free Abortions'.

The buildings in New Delhi, erected almost as a last act by the British, the view from them of the Gate of India and the Embassy buildings are magnificent but how could any government develop such a vast country, with its conflicting religions and classes? Possibly as another legacy from the 
British Raj, the conduct of affairs is authoritarian and bureaucratic, so that there are interminable queues at the airports while officials stamp, write in documents, operate computers, search baggage and enquire in detail about its contents. Drabness is relieved by the colour of the saris.

From a listening post in a Mogul Fort high above Jaipur my wife and I heard at sunset the ascending murmur of the city. In Udaipur we saw that the desert was transformed by artificial lakes backed by mountains into lovely scenes which even the ubiquity of cow dung dises saved for fuel could not spoil. At the Taj Mahal, with its intricately beautiful inlaid stonework, there was a group of carefree and playful young Russians. In Delhi among the temples, mosques, Mogul Red Fort and streets crowded with people, cows and a medley of transport, was the simple grandeur of the Gandhi memorial in black marble. Our last trip was to Kashmir, where the natives pushed us to and from our houseboat in a small boat on a frozen lake. They kept themselves and us warm with glowing coals in a metal pan surrounded by a wicker basket, which they put under their rough woollen cloaks, so that by the end of winter their abdomens would be scarred. The snow had reduced the Shalimar gardens to a homogenous whiteness but there was sunshine and skiing up in the Himalayas.

\title{
The Red Handbook: an historic centenary
}

\author{
Henry R. Rollin, Emeritus Consultant, Horton Hospital, Epsom, Surrey
}

On 21 February 1884, a sub-committee of the MedicoPsychological Association meeting in Glasgow was appointed to prepare a handbook 'in the hope of helping Attendants on the insane to a due understanding of the work in which they are engaged'. With commendable speed the four gentlemen concerned, Drs A. Campbell Clark, C. McIvor Campbell, A. R. Turnbull and A. R. Urquart, completed their allotted task, and in 1885 The Handbook For The Instruction Of Attendants On The Insane was published.

It emerged as a slim volume, bound in red hardboard, and consisted of 64 pages of text together with an Appendix listing all the public and private Lunatic Asylums in the United Kingdom and their Superintendents. The text was divided into five chapters under the headings:

I The Body, its general functions and disorders;

II The Nursing of the Sick;

III Mind, and its disorders;

IV The Care of the Insane;

V The General Duties of Attendants.

In 1885, The Journal of Mental Science (31, 149), published a snooty and patronising review of the book. "We are not quite sure ourselves whether it is necessary or wise to attempt to convey instructions in physiology, etc., to ordinary attendants. Will they be the better equipped for their duties for being told that the brain consists of grey and white matter and cement substance?", writes the anonymous reviewer. He adjusts his elegant pince-nez and continues, "We hardly see what is to be gained by superficial knowledge of this kind."

Considering the book's brevity and the ambitious scope of its contents, it is not surprising that the information it contained was of necessity condensed and elementary. But it was a start; and not only a start, but, as it turned out, the handbook served as a most important milestone in the history of the education of 'Attendants on the Insane', who must hitherto have been regarded as little more than pairs of hands.

That the labours of the Glasgow sub-committee were fully justified, and the forebodings of the anonymous reviewer in the Journal of Mental Science wholly unjustified, are reflected in the enormous success which its handbook and its successors have enjoyed in the century since the original publication. Indeed, within the covers of the many editions, gallantly attempting to keep pace with developments in the field, is contained a condensed history of British psychiatry.

The handbook has always been published in conjunction with the Medico-Psychological Association, and later the Royal Medico-Psychological Association, albeit over the years it has undergone some changes in title and format. For example, the seventh edition, published in 1923, was renamed The Handbook for Mental Nurses, but it was known more familiarly, even affectionately, by generations of psychiatric nurses as 'The Red Handbook'.

In April 1964, the ninth edition appeared under the editorship of the late Brian Ackner who enlisted a bevy of contributors, not only psychiatrists, all of them acknowledged experts in their own field, but also a senior psychiatric social worker and a superintendent of nursing. There were 335 pages of text, a suggested reading list, and a glossary of terms used in the text. This particular edition was reprinted six times, the last of which was in June 1978.

In 1979, the education committee of the Royal College of Psychiatrists considered that the book was out of date and decided, no doubt for very good reasons, not to commission a further edition. Nevertheless, that the book has not yet outlived its usefulness is well illustrated by the fact that the copy of the last edition I took down from the shelves of the library at Horton Hospital School of Nursing, Epsom, is regularly borrowed, the last occasion being as recently as 29 May 1986! 